Article

\title{
Tomato Breeding for Sustainable Crop Systems: High Levels of Zingiberene Providing Resistance to Multiple Arthropods
}

\author{
João Ronaldo Freitas de Oliveira $\left.{ }^{1} \mathbb{(}\right)$, Juliano Tadeu Vilela de Resende ${ }^{2}($, \\ Renato Barros de Lima Filho ${ }^{1}{ }^{(}$, Sergio Ruffo Roberto ${ }^{2, *(\mathbb{C})}$, Paulo Roberto da Silva ${ }^{3}{ }^{\circ}$, \\ Caroline Rech $^{1}$ (D) and Cristiane Nardi $^{1}$ (D) \\ 1 Department of Agronomy, Midwestern State University, Simeão Camargo Varela de Sá 03, Vila Carli, \\ Guarapuava, Paraná ZIP 85040-080, Brazil; joaoroliveira@yahoo.com.br (J.R.F.d.O.); \\ delimafilho.renato@yahoo.com (R.B.d.L.F.); caroline_rech@outlook.com (C.R.); cnardi@alumni.usp.br (C.N.) \\ 2 Agricultural Research Center, Londrina State University, Celso Garcia Cid Road, km 380, P.O. Box 10.011, \\ Londrina ZIP 86057-970, Brazil; jvresende@uel.br \\ 3 Genetics and Plant Molecular Biology Laboratory, Midwestern State University, \\ Simeão Camargo Varela de Sá 03, Vila Carli, Guarapuava, Paraná ZIP 85040-080, Brazil; \\ prsilva@unicentro.br \\ * Correspondence: sroberto@uel.br
}

Received: 13 April 2020; Accepted: 29 May 2020; Published: 5 June 2020

\begin{abstract}
In sustainable cropping systems, the management of herbivorous arthropods is a challenge for the high performance of the tomato crop. One way to reduce the damage caused by these pests is the use of resistant cultivars within a sustainable integrated management system. The host selection of Tetranychus urticae, Bemisia tabaci, and Tuta absoluta was evaluated, characterizing their preference among the tomato genotypes RVTZ2011-79-503-143, RVTZ2011-79-335-164, RVTZ2011-79-185-250 (high zingiberene content-HZC), and RVTZ2011-79-117-273 (low zingiberene content-LZC). Such genotypes were selected in the $\mathrm{F}_{2} \mathrm{BC}_{2}$ generation (the $\mathrm{F} 2$ generation of the 2th backcross towards Solanum lycopersicum after the inicial interspecific cross S. lycopersicum $\times$ S. habrochaites var. hirsutum), resulting from crossing Solanum habrochaites var. hirsutum PI-127826 (HZC and resistant to mites) and the commercial cv. Redenção (S. lycopersicum) (LZC and susceptible to mites). In choice and no-choice bioassays by T. urticae, and in choice bioassays by B. tabaci and T. absoluta, arthropods preferred to stay and oviposit in an LZC genotype. In contrast, genotypes with HZC showed repellency to pests and induced a non-preference for oviposition. The $\mathrm{F}_{2} \mathrm{BC}_{2}$ genotypes selected for $\mathrm{HZC}$ are considered sources of resistance genes to these pests for tomato breeding programs, and therefore have excellent potential for sustainable cropping systems. These results represent an advance in obtaining tomato genetic materials which can be used in sustainable production systems with less loss from pests.
\end{abstract}

Keywords: genetic resistance; natural allelochemicals; organic production; plant defense

\section{Introduction}

The adoption of genetically resistant plant materials is one of the main strategies for pest management in sustainable tomato crops, in which the use of pesticides should be reduced or mitigated due to their adverse effects on the environment and human health [1-3]. A large number of biochemical and morphological characteristics have been related to tomato resistance to several key and secondary crop pests. Biochemical factors such as allelochemicals, proteins, and several metabolites are often associated with the morphological structures of species like trichomes, mesoderm, and parenchyma, among many other [4-6]. The introgression of genes from wild species has been shown to be the 
main alternative for tomato breeding programs, as there are several records of resistance in relation to arthropod pest species in this crop [7-12].

As a way to identify and measure the resistance of tomato genotypes to pest arthropods, biological and behavioral bioassays have been used to characterize cultivars that have resistance mechanisms of the antibiosis or antixenosis type to herbivores in comparison to susceptibility patterns [13]. Thus, it is also possible to identify the mechanisms and degrees of resistance of seedlings to the investigated pest arthropods. In tomato, the resistance mechanism of wild species is associated with the presence and exudation of allelochemicals present mainly in glandular trichomes of stems, leaves, and fruit [14-18]. Zingiberene is an allelochemical with deterrent and repellent actions against pest arthropods, and was found in high concentrations in Solanum habrochaites var. hirsutum PI-127826 in the glandular trichomes of types IV and VI [19-21]. The inheritance of the content of this allelochemical shows a high heritability, with values above $80 \%$; it is controlled by two genes with incomplete dominance, which allows genetic gains regarding resistance when selecting seedlings with high zingiberene content [22-25].

Recently, the tomato genotype access PI-127826 was been used to increase the degrees of resistance in commercial varieties of Solanum lycopersicum though interspecific crosses [20,25-27] in order to obtain isogenic lines for hybrid production in conventional and sustainable production systems. However, the reactions triggered by the allelochemicals on the pests have been varied and complex, resulting in different levels of response in relation to the attack. Therefore, it is necessary to understand the effect of zingiberene and its stereoisomers on the behavior and biology of arthropod pests to determine the level of resistance of the genotypes. In addition, for a tomato breeding program, it is essential to characterize the resistance of generations and confirm the presence of the desirable characteristics of the parents which can be employed in future crossings.

Among the pest arthropods that occur in tomato, Tuta absoluta (Meyrick) (Lepidoptera: Gelechiidae), Bemisia tabaci (Gennadius) (Hemiptera: Aleyrodidae) and Tetranychus urticae (Koch) (Acari: Tetranychidae) are cosmopolitan and recurrent in crops grown in diverse production systems. For these arthropods, the deleterious effect of zingiberene has been evidenced in genotypes related to S. habrochaites var. hirsutum. However, despite all the studies on this subject, obtaining commercial cultivars with acceptable levels of yield and resistance is still an objective yet to be achieved [6,28-32].

In order to characterize resistant tomato genotypes to be used in breeding programs, we investigated the degrees of resistance of $\mathrm{F}_{2} \mathrm{BC}_{2}$ genotypes with high levels of zingiberene which were obtained from interspecific crossing between S. habrochaites var. hirsutum and S. lycopersicum. The resistance degree of the genotypes to T. urticae, B. tabaci, and T. absoluta were verified upon host selection bioassays.

\section{Material and Methods}

\subsection{Location}

The bioassays were carried out at the Midwestern Parana State University, Guarapuava, Paraná, Brazil $\left(25^{\circ} 23^{\prime} 00^{\prime \prime} \mathrm{S}, 51^{\circ} 29^{\prime} 38.50^{\prime \prime} \mathrm{W}\right.$, elevation 1024 m.a.s.l.). The local climate is classified as humid subtropical mesothermal ( $\mathrm{Cfb}$ ), with moderate summers, winters with frost incidence, and an average annual rainfall of $1711 \mathrm{~mm}$.

\subsection{Tomato Genotypes and Growing Seedlings}

The tomato genotypes selected by Zanin et al. [25] from a $\mathrm{F}_{2} \mathrm{BC}_{1}$ population for high levels of zingiberene (RVTZ 2011-079-117, RVTZ 2011-079-185, RVTZ 2011-079-335, and RVTZ 2011-079-503) were used as parents and pollen sources for crosses with Solanum lycopersicum cv. Redenção, thus obtaining the $\mathrm{F}_{1} \mathrm{RC}_{2}$ generation which, after self-fertilization, originated the $\mathrm{F}_{2} \mathrm{BC}_{2}$ population.

The selection of contrasting genotypes occurred in 400 seedlings of the $\mathrm{F}_{2} \mathrm{BC}_{2}$ population. The levels of zingiberene were quantified in young and expanded leaflets according to the methodology proposed by de Freitas et al. [33]. Therefore, six leaf disks (1 cm in diameter) were sampled from each genotype, 
placed in tubes containing $2 \mathrm{~mL}$ of hexane, and then vortexed for $30 \mathrm{~s}$. After that, the leaf disks were removed and the absorbance of the solution was measured using a spectrophotometer (Cary series, UV-Vis Spectrophotometer) at a wavelength of $270 \mathrm{~nm}$. The selection of genotypes was carried out based on the absorbance values, which were above $0.300 \mathrm{~nm}$ for the thee high-zingiberene genotypes and below $0.150 \mathrm{~nm}$ for the low-zingiberene genotype.

As low and high allelochemical standards, 50 tomato seedlings of cv. Redenção and 50 seedlings of the wild genotype $S$. habrochaites var. hirsutum, respectively, were used.

The $\mathrm{F}_{2} \mathrm{BC}_{2}$ genotypes selected indirectly for laboratory resistance based on zingiberene content were RVTZ 2011-79-503-143, RVTZ 2011-79-503-164, RVTZ 2011-79-503-250 (high zingiberene content-HZC) and, to use as a susceptibility standard in bioassays, RVTZ 2011-79-117-273 (low zingiberene content-LZC) (Table 1). The genotypes were cloned from axillary shoots; rooted; transplanted into polyethylene pots (5 L) containing a mixture of commercial substrate and soil (1:1), nitrogen, phosphorus and potassium chemical fertilizer (4:14:8), and acidity correction according to crop demand.

Table 1. Absorbancy at $270 \mathrm{~nm}$ (means \pm SD) indicating the zingiberene content of tomato genotypes (Solanum lycopersicum cv. Redenção, Solanum habrochaites var. hirsutum, and genotypes of $\mathrm{F}_{2} \mathrm{BC}_{2}$ ).

\begin{tabular}{ccc}
\hline Genotype & Absorbancy (270 $\mathbf{~ n m )}$ & Classification \\
\hline S. lycopersicum cv. Redenção & $0.032 \pm 0.01$ & Susceptible standard (SS) \\
RVTZ 2011-79-117-273 & $0.100 \pm 0.05$ & Low zingiberene content (LZC) \\
RVTZ 2011-79-335-164 & $0.322 \pm 0.04$ & High zingiberene content (HZC) \\
RVTZ 2011-79-185-250 & $0.330 \pm 0.07$ & High zingiberene content (HZC) \\
RVTZ 2011-79-503-143 & $0.809 \pm 0.18$ & High zingiberene content (HZC) \\
S. habrochaites var. hirsutum & $0.946 \pm 0.19$ & Resistant standard (RS) \\
\hline
\end{tabular}

\subsection{Arthropod Rearing}

Adults of T. urticae were collected and kept on common bean seedlings (Phaseolus vulgaris), under controlled conditions $\left(25 \pm 2{ }^{\circ} \mathrm{C}, 70 \% \pm 4 \%\right.$ relative humidity- $\mathrm{RH}, 12 \mathrm{~h}$ photophase), with daily irrigation. The age-controlled breeding consisted of 10 adult mites ( 3 males and 7 females) kept on individual bean leaflets, arranged on a sponge moistened with distilled water, and packed in plastic trays $(200 \times 300 \mathrm{~mm})$ with the bottom facing up. The mites were kept on the leaflets for $24 \mathrm{~h}$ and then the adults were removed, leaving only the eggs.

Individual B. tabaci and T. absoluta were collected in greenhouses from tomatoes in commercial production. For the rearing of $B$. tabaci, individuals were kept and multiplied on common bean seedlings, grown in pots, and packed in cages in a greenhouse at $25 \pm 3{ }^{\circ} \mathrm{C}$ with daily irrigation. Rearing for age control was carried out, keeping bean seedlings with $B$. tabaci nymphs in cages made of voile fabric $(100 \times 100 \mathrm{~cm})$ in a protected environment free from infestation. From five to eight days after emergence, the adults were used for bioassays. To rear T. absoluta, the individuals were kept on tomato seedlings cv. Santa Cruz, grown in pots, and placed in voile cages $(100 \times 100 \mathrm{~cm})$ in a greenhouse at $25 \pm 3{ }^{\circ} \mathrm{C}$. The eggs deposited on the leaves were removed at intervals of three days and transferred to similar cages containing seedlings free from infestation.

\subsection{Host Selection Bioassays}

\subsubsection{Tetranychus urticae}

Choice and no-choice bioassays were carried out in Petri dish arenas $(6 \mathrm{~cm}$ in diameter) and covered with a sponge and a cotton layer both moistened in distilled water. In each choice test dish, two leaf discs ( $3 \mathrm{~cm}$ in diameter) were placed under the cotton layer with the abaxial region facing upwards. Two genotypes were placed in each dish, and all of them were tested in combination two by two in order to evaluate the preference of the mites (Figure 1a). The discs were connected to each other 
by a transparent coverslip $(18 \times 18 \mathrm{~mm})$, in the center of which four adult females of T. urticae were released, allowing free choice between the discs of the different tomato genotypes. The dishes were kept for $24 \mathrm{~h}$ in an air-conditioned chamber $\left(25 \pm 1{ }^{\circ} \mathrm{C}, 70 \% \pm 4 \% \mathrm{RH}, 12 \mathrm{~h}\right.$ photophase). Then, the live mites present on each leaf disc were counted, in addition to the eggs deposited on the leaf surface.
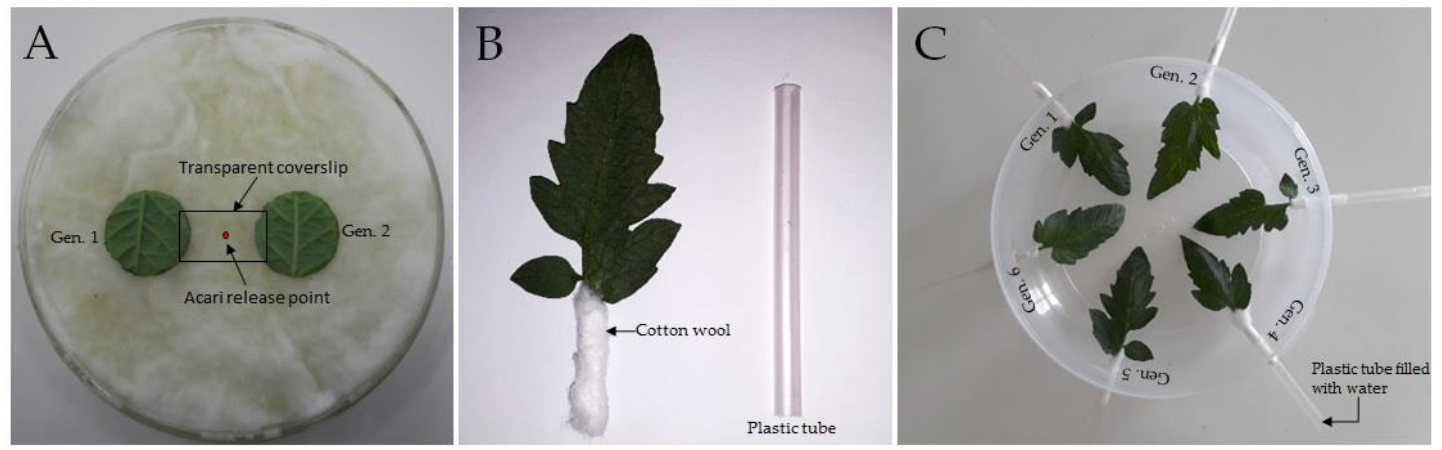

Figure 1. Material used in the host selection bioassays. (A) Arena for Tetranychus urticae with two tomato genotypes connected by a transparent coverslip where the mites were released. (B) Tomato leaflet wrapped in cotton wool and plastic tube. (C) Tomato genotypes (6 treatments) arranged equidistant presenting the design of the Bemisia tabaci and Tuta absoluta bioassays. Each leaflet wrapped in cotton wool was introduced into a plastic tube containing water in order to maintain the humidity.

The experiment was designed with six treatments (genotypes) that were combined in pairs (total of 14 combinations) with ten repetitions per pair, and the arenas were distributed in a completely randomized design.

For the no-choice test, a leaf disc ( $3 \mathrm{~cm}$ in diameter) of each genotype was inserted in each arena, on which six adult females were transferred with the aid of a stereoscopic microscope (Nikon SMZ745T, Japan). The females were kept on the leaf discs for $24 \mathrm{~h}$, and then the live mites and eggs deposited on the abaxial face of each disc were counted. The experiment was carried out in a completely randomized design, with six treatments (genotypes) and ten repetitions. The dishes were kept in an air-conditioned chamber $\left(25 \pm 1{ }^{\circ} \mathrm{C}, 70 \% \pm 4 \% \mathrm{RH}, 12 \mathrm{~h}\right.$ photophase).

\subsubsection{Bemisia tabaci}

To evaluate the host selection behavior for the oviposition of $B$. tabaci, a choice test was adopted using circular plastic arenas $(29.0 \mathrm{~cm}$ in diameter $\times 10.0 \mathrm{~cm}$ in height) with the cover lined with voile fabric to allow air circulation. From six equidistant holes in the side walls of the arena, tomato leaflets were inserted in a horizontal position, with the petiole kept externally and the leaf area internally within the arena. In order to keep the leaflet moist, the petiole was wrapped in cotton wool before being inserted into the plastic tube $(0.3 \mathrm{~cm}$ in diameter $\times 10.0 \mathrm{~cm}$ in length) filled with water, whose function was to keep the cotton and petiole moist (Figure 1B,C). Thus, each arena contained a leaflet of each tomato genotype, comprising six leaflets, which were available for the choice of the insects.

In each arena, 30 individuals of $B$. tabaci were inserted and released with the aid of a suction device (transparent plastic tube $0.3 \mathrm{~cm}$ in diameter) from a hole made in the bottom of the container. After $24 \mathrm{~h}$, the individuals and eggs present on the abaxial face of each leaflet were counted in order to calculate the attractive and preference index.

This bioassay was carried out in a completely randomized design with 6 treatments (genotypes) and 20 repetitions, and the arenas were kept in a greenhouse with temperature control $\left(25 \pm 3^{\circ} \mathrm{C}\right)$.

\subsubsection{Tuta absoluta}

The behavior and deposition of the T. absoluta were evaluated in choice bioassays, using arenas similar to those described above for B. tabaci, allowing the free choice of insects in relation to the genotypes. However, for T. absoluta the arenas were made with a rectangular EVA 
(ethylene vinyl acetate) plate arranged in a conical shape forming a tube $(25.0 \mathrm{~cm}$ in diameter $\times$ $40.0 \mathrm{~cm}$ in height), with side holes arranged in an equidistant way, which allowed the coupling of the leaflets in the horizontal position. The leaflets were inserted in the arena with the leaf area on the inside and the petiole wrapped in cotton and a plastic tube on the outside (Figure 1B,C). In turn, the upper and lower openings of the arena were lined with voile fabric to prevent the escape of insects and to allow air to circulate.

In the center of each arena, 12 females were released (10 to 12 days old), which remained for $72 \mathrm{~h}$ until the number of individuals and the number of eggs deposited on the adaxial and abaxial surfaces of the leaflets of each genotype were evaluated.

The bioassay was carried out in a completely randomized design, with 6 treatments (genotypes) and 10 repetitions. The insects were kept in air-conditioned rooms $\left(25 \pm 1{ }^{\circ} \mathrm{C}, 70 \% \pm 4 \% \mathrm{RH}\right.$, photophase $12 \mathrm{~h})$.

\subsection{Data Analysis}

The number of adults and eggs of T. urticae, B. tabaci, and T. absoluta present in each treatment in the choice and no-choice tests were submitted to a normality analysis (Bartlet, $p \leq 0.05$ ) and analysis of variance (ANOVA, $p \leq 0.05)$, and the means were compared by the Tukey test $(\alpha \leq 0.05)$. The non-normal data were transformed by $(x+0.5)^{1 / 2}$. These analyses were performed using the Statistica 7.0 software [34].

The data referring to the choice bioassays for T. urticae were analyzed using the Chi-square test $(p \leq 0.05)$ and Kruskal-Wallis $(p \leq 0.05)$, respectively, to test the hypothesis of equality between the observed and expected frequencies from individuals in each treatment.

In the choice bioassays for $B$. tabaci and T. absoluta, the attractiveness index was estimated as $\mathrm{AI}=2 \mathrm{G} /(\mathrm{G}+\mathrm{S})$, where $\mathrm{AI}=$ attractiveness index; $\mathrm{G}=$ number of insects attracted to the evaluated genotype; and $S=$ number of insects attracted to the susceptible standard (S. lycopersicum cv. Redenção). The AI values varied between zero and two, in which $\mathrm{AI}=1$ indicates a similar attraction between the evaluated genotypes (repellent test plant) and the standard (attractive test plant); $\mathrm{AI}<1$ corresponds to less attraction (greater repellency) to the genotype; and $\mathrm{AI}>1$ indicates a greater attraction to the evaluated genotype in relation to the standard. This index is an adaptation of the formula mentioned by Lin et al. [35] and used by Baldin et al. [36].

The oviposition preference index $(\mathrm{OPI})$ was also calculated as OPI $=[(\mathrm{T}-\mathrm{S}) /(\mathrm{T}+\mathrm{S})] \times 100$, where $\mathrm{T}=$ number of eggs counted in the evaluated treatment and $\mathrm{S}=$ number of eggs counted in the standard genotype (S. lycopersicum cv. Redenção). This index ranges from +100 (high preference) to -100 (non-preference or oviposition inhibition). The classification of genotypes was performed by comparing the average of eggs from the treatments with the average of the S. lycopersicum $\mathrm{cv}$. Redenção [37].

\section{Results}

\subsection{Tetranychus Urticae Host Selection}

The combinations of genotypes offered to T. urticae influenced the choice of females, which showed a rejection of the $\mathrm{F}_{2} \mathrm{BC}_{2}$ genotypes with HZC (RVTZ 2011-79-503-143, RVTZ 2011-79-503-164, and RVTZ 2011-79-503-250) when combined with the standard susceptibility tomato cv. Redenção (Chi-square, $\mathrm{GL}=1, p<0.05$ ) (Figure 2). Although it was with less intensity, this response pattern was repeated when this cultivar was compared to the low-zingiberene genotype (RVTZ 2011-79-503-273) (Chi-square, $\mathrm{GL}=1, p=0.016$ ). 


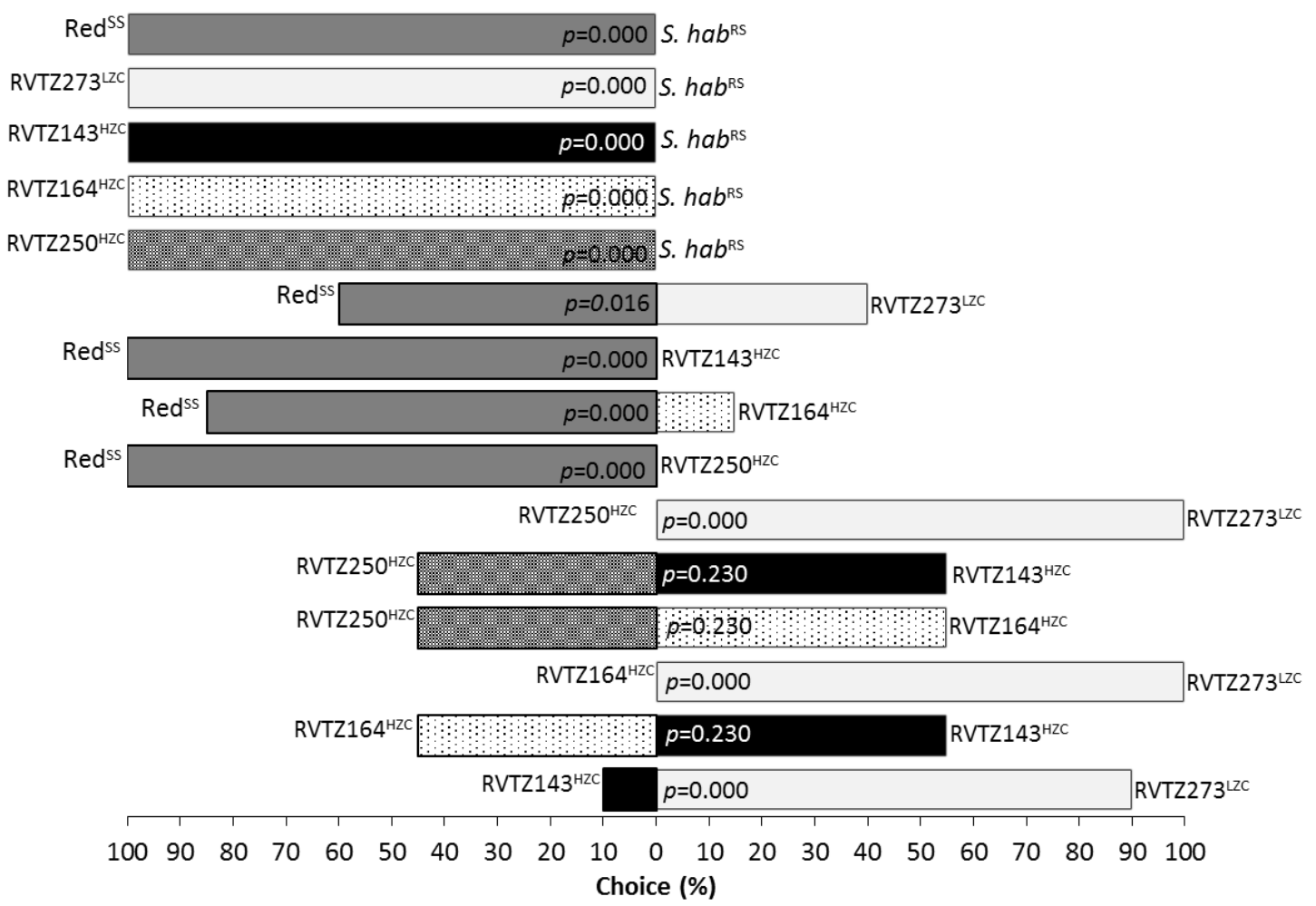

Figure 2. Frequency of choice of Tetranychus urticae in relation to tomato $\mathrm{F}_{2} \mathrm{BC}_{2}$ genotypes $(n=10)$. Red = Solanum lycopersicum cv. Redenção; PI-127826 = Solanum habrochaites var. hirsutum PI-127826; $273=$ RVTZ 2011-79-117-273 (with low zingiberene content); $143=$ RVTZ 2011-79-503-143; $164=$ RVTZ 2011-79-503-164; and 250 = RVTZ 2011-79-503-250 (with high zingiberene content). $p$-value indicates the statistical significance according to the Chi-square test. SS = Susceptible Standard genotype; RS = Resistant standard genotype; HZC = high zingiberene content; LZC = low zingiberene content.

Less attractiveness compared to the standard resistance genotype $S$. habrochaites var. hirsutum PI-127826 was observed in all the evaluated combinations, even when compared to the genotypes selected for HZC in the $\mathrm{F}_{2} \mathrm{BC}_{2}$ generation (Chi-square, $\mathrm{GL}=1, p<0.05$ ). T. urticae females did not differentiate between the genotypes with HZC, presenting a similar frequency of choice regardless of the combined genotypes (Chi-square, $\mathrm{GL}=1, p>0.05$ ).

In no-choice bioassays, the number of live mites was influenced by the presence of zingiberene. S. lycopersicum cv. Redenção leaflets provided more than $90 \%$ survival after $24 \mathrm{~h}$ of exposure of mites, with an average of 5.75 living individuals. The LZC genotype RVTZ 2011-79-117-273 did not differ from the standard susceptible genotype (Tukey, $\mathrm{GL}=5, \alpha=0.912$ ). In turn, HZC triggered acari mortality, as occurred with the resistant standard genotype (Tukey, GL $=5, \alpha<0.0001$ ). The average number of eggs deposited in the leaflets was higher in the susceptible cultivar and in the low allelochemical genotype, differing from the high-content genotypes (Tukey, GL $=5, \alpha<0.0001$ ). These genotypes did not differ among themselves (Tukey, $\mathrm{GL}=5, \alpha>0.1$ ) (Table 2).

\subsection{Bemisia tabaci Host Selection}

S. lycopersicum cv. Redenção was the most attractive for permanence and oviposition, followed by RVTZ 2011-79-117-273 (LZC) (Tukey, GL $=5, p=0.01$ ). S. habrochaites var. hirsutum PI-127826 and other genotypes selected for their high levels of zingiberene triggered the same insect responses (RVTZ 2011-79-503-143, RVTZ 2011-79-335-164, RVTZ 2011-79-185-250) (Tukey, GL = 5, $\alpha>0.9$ ) (Table 3). 
Table 2. Number ( \pm standard error) of live adults and eggs of Tetranychus urticae mites on the abaxial face of leaf discs of tomato genotypes in no-choice oviposition bioassays $(n=10)$.

\begin{tabular}{ccc}
\hline Genotypes & Number of Individuals & Number of Eggs \\
\hline Solanum lycopersicum cv. Redenção & $5.75 \pm 0.12 \mathrm{a}$ & $46.6 \pm 1.80 \mathrm{a}$ \\
RVTZ 2011-79-117-273 LZC & $4.25 \pm 0.14 \mathrm{ab}$ & $27.2 \pm 1.20 \mathrm{~b}$ \\
RVTZ 2011-79-503-143 HZC & $3.25 \pm 0.15 \mathrm{~b}$ & $3.1 \pm 0.60 \mathrm{c}$ \\
RVTZ 2011-79-335-164 HZC & $3.50 \pm 0.14 \mathrm{~b}$ & $3.9 \pm 0.53 \mathrm{c}$ \\
RVTZ 2011-79-185-250 HZC & $3.25 \pm 0.30 \mathrm{~b}$ & $0.7 \pm 0.14 \mathrm{c}$ \\
Solanum habrochaites var. hirsutum & $3.75 \pm 0.12 \mathrm{~b}$ & $1.8 \pm 0.18 \mathrm{c}$ \\
\hline F-value & 81.9 & 328 \\
ANOVA $p$-value & 0.03 & 0.0001 \\
\hline
\end{tabular}

LZC low zingiberene content; ${ }^{H Z C}$ high zingiberene content. Means followed by the same letter in a column do not differ statistically from each other by the Tukey test $(\mathrm{GL}=5, \alpha \leq 0.05)$. For analysis, the average number of eggs was transformed by $(x+0.5)^{1 / 2}$.

Table 3. Number ( \pm standard error) of Bemisia tabaci live adults and eggs on the abaxial face of leaflets from tomato genotypes in the choice bioassay $(n=10)$.

\begin{tabular}{ccc}
\hline Genotypes & Number of Individuals & Number of Eggs \\
\hline Solanum lycopersicum cv. Redenção & $13.00 \pm 0.90 \mathrm{a}$ & $47.10 \pm 3.70 \mathrm{a}$ \\
RVTZ 2011-79-117-273 LZC & $12.90 \pm 1.0 \mathrm{~b}$ & $35.30 \pm 3.50 \mathrm{~b}$ \\
RVTZ 2011-79-503-143 HZC & $0.70 \pm 0.20 \mathrm{c}$ & $1.45 \pm 0.50 \mathrm{c}$ \\
RVTZ 2011-79-335-164 HZC & $1.20 \pm 0.30 \mathrm{c}$ & $1.80 \pm 0.40 \mathrm{c}$ \\
RVTZ 2011-79-185-250 HZC & $1.00 \pm 0.15 \mathrm{c}$ & $1.75 \pm 0.35 \mathrm{c}$ \\
Solanum habrochaites var. hirsutum & $1.20 \pm 0.30 \mathrm{c}$ & $2.50 \pm 0.40 \mathrm{c}$ \\
\hline F-value & 683.8 & 177.8 \\
ANOVA $p$-value & 0.0001 & 0.0001
\end{tabular}

LZC low zingiberene content; ${ }^{\text {HZC }}$ high zingiberene content. Means followed by the same letter in each column do not differ statistically from each other by the Tukey test $(\alpha \leq 0.05)$. For analysis, the average number of eggs was transformed by $(x+0.5)^{1 / 2}$.

According to the values of the attractiveness index calculated after $24 \mathrm{~h}$ of infestation, all the genotypes with a HZC were classified as repellent to B. tabaci when compared to the susceptible standard genotype S. lycopersicum cv. Redenção (Figure 3a). In addition, the preference index for oviposition calculated in the choice bioassay classified all the materials as non-preferred to B. tabaci oviposition when compared to the susceptible S. lycopersicum cv. Redenção, even for the low zingiberene genotype (Figure $3 b$ ).

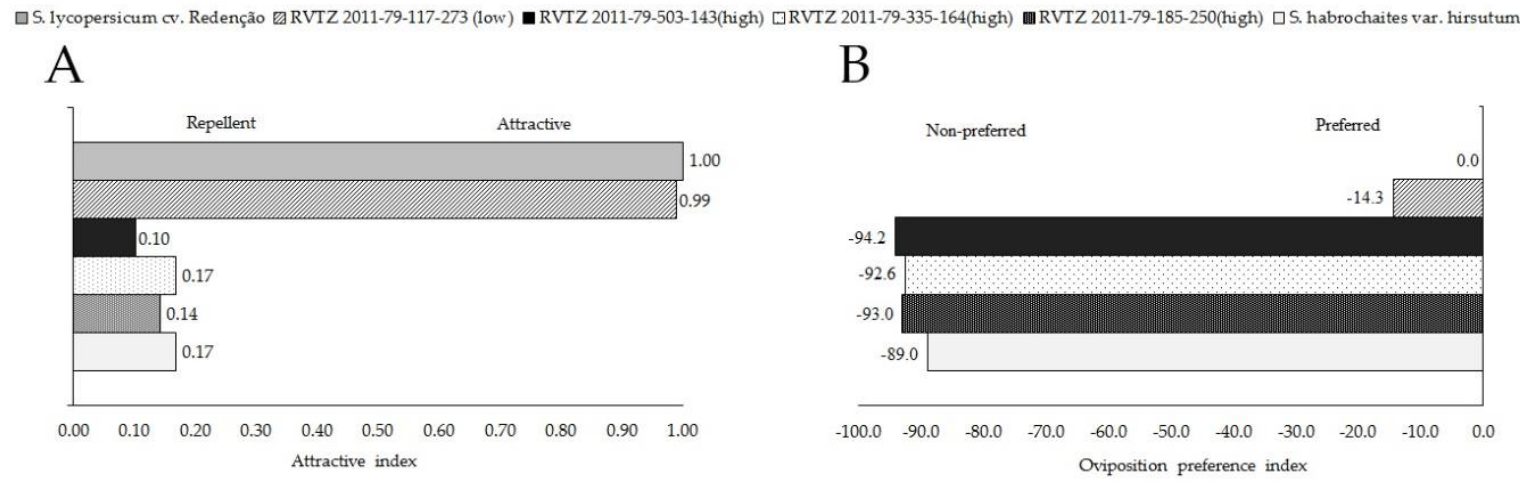

Figure 3. Bemisia tabaci responses to tomato genotypes in choice bioassays $(n=10)$. (A) Attractiveness index of genotypes for adults of B. tabaci. (B) Oviposition preference index for B. tabaci in relation to genotypes. The data regarding the number of individuals were transformed by $(x+0.5)^{1 / 2}$. 


\subsection{Tuta Absoluta Host Selection}

T. absoluta females preferred to remain in the LZC genotypes. Nevertheless, they did not differ from RVTZ 2011-79-335-164, which was selected for the high content of this compound (Tukey, GL = 5, $\alpha>0.1$ ) (Table 4). However, even in the genotype with a HZC, T. absoluta females oviposited compared to the susceptible standard and that with a LZC (Tukey, GL $=5, \alpha<0.05$ ) (Table 4). Therefore, the number of eggs deposited was significantly higher in the standard susceptibility cultivar than in the other genotypes (Tukey, GL $=5, \alpha<0.05$ ) (Table 4 ).

Table 4. Number ( \pm standard error) of Tuta absoluta adults and eggs on the adaxial and abaxial sides of leaflets of tomato genotypes in a choice bioassay $(n=10)$.

\begin{tabular}{ccc}
\hline Genotypes & Number of Adults & Number of Eggs \\
\hline Solanum lycopersicum cv. Redenção & $1.4 \pm 0.15 \mathrm{a}$ & $47.0 \pm 1.40 \mathrm{a}$ \\
RVTZ 2011-79-117-273 LZC & $1.4 \pm 0.15 \mathrm{a}$ & $37.0 \pm 1.30 \mathrm{~b}$ \\
RVTZ 2011-79-503-143 HZC & $0.5 \pm 0.16 \mathrm{~b}$ & $4.7 \pm 0.10 \mathrm{c}$ \\
RVTZ 2011-79-335-164 HZC & $1.0 \pm 0.2 \mathrm{ab}$ & $8.2 \pm 0.30 \mathrm{c}$ \\
RVTZ 2011-79-185-250 HZC & $0.6 \pm 0.15 \mathrm{~b}$ & $9.1 \pm 0.20 \mathrm{c}$ \\
Solanum habrochaites var. hirsutum & $0.5 \pm 0.16 \mathrm{~b}$ & $3.6 \pm 0.09 \mathrm{c}$ \\
\hline F-value & 6.1 & 111.6 \\
ANOVA $p$-value & 0.0001 & 0.0001
\end{tabular}

LZC low zingiberene content; ${ }^{H Z C}$ high zingiberene content. Means followed by the same letter in each column do not differ statistically from each other by the Tukey test $(\alpha \leq 0.05)$. For analysis, the average number of eggs was transformed by $(x+0.5)^{1 / 2}$.

The calculated indices demonstrated that the LZC and susceptible genotypes were more attractive to T. absoluta than the genotypes with a HZC (Figure 4a). In contrast, the HZC genotypes presented less attractiveness (RVTZ 2011-79-335-164 and RVTZ 2011-79-185-250) or repellency (RVTZ 2011-79-503-143) to T. absoluta (Figure 4a). Furthermore, the selected HZC genotypes suppressed T. absoluta oviposition, triggering more than $60 \%$ of the oviposition index when compared with the standard genotype (S. lycopersicum cv. Redenção) (Figure 4b).

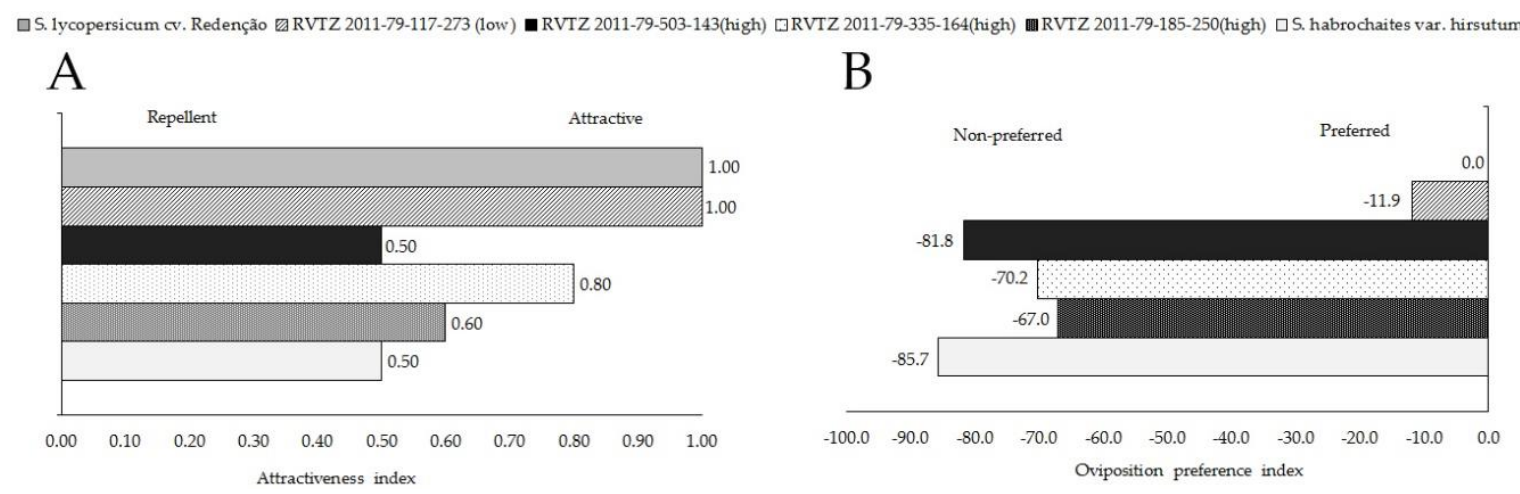

Figure 4. Tuta absoluta responses to tomato genotypes in choice bioassays. (A) Attractiveness index of genotypes for adults of T. absoluta. (B) Oviposition preference index of T. absoluta in relation to genotypes. The data regarding the number of individuals were transformed by $(x+0.5)^{1 / 2}$.

\section{Discussion}

Genetics and plant breeding are two main sciences in the service of man that contribute in various fields of activities, especially food production. Genetic improvement considers the relationship of physical, chemical, biological, economic, and social components to the environment, aiming at the best possible adjustment and resulting in the sustainability of a productive system. Thus, genetic improvement is essential for plants to adapt sustainably to the growing environment, providing greater productivity and less possible damage to the system balance. 
Tomato production is characterized by low sustainability, largely due to the high number of applications for pest and disease control. In this context, breeding aimed at the greater sustainability of the systems has sought to develop genotypes more tolerant to abiotic and biotic stresses. The use of wild tomato genotypes as a source of resistance to pests has been used on a recurring basis, aiming to seek adjustment to the sustainable production system.

The resistance in these cases is related to the presence of allelochemicals that are exuded by the tomato leaf trichomes, including zingiberene, a volatile sesquiterpene with a proven effect in pest control. The best way to introduce resistance in commercial cultivars is though interspecific crossings. In the present work, resistance was introduced though backcrosses and, as shown, the results were promising.

Glandular trichomes are specialized structures found on the surface of about $30 \%$ of all vascular plants and are responsible for a significant portion of a plant's secondary chemistry. Glandular trichomes are an important source of allelochemicals, which provide the plant with protection against herbivores and pathogens. The storage compartment of glandular trichomes is usually located at the tip of the morphological structure and is part of the glandular cell, or cells that are metabolically active. This knowledge now helps classic breeding programs, as well as targeted genetic engineering, with the aim of optimizing the density and physiology of trichomes for the purpose of biocides to improve crop protection $[38,39]$

Glandular trichomes and zingiberene contribute to increased tomato resistance against herbivore attack [39]. The ability to accumulate zingiberene in glandular trichomes is being transferred to commercial cultivars through crossbreeding, contributing to the increased resistance of plants to mites and whiteflies [40]. The presence of zingiberene in tomato genotypes induced a non-preference for the oviposition of arthropod pests. Such evidence demonstrates that $\mathrm{F}_{2} \mathrm{BC}_{2}$ seedlings selected for high zingiberene content have desirable degrees of resistance to arthropods, and that selection for this characteristic has been successful in terms of the biological response of the target organisms. These genotypes, in some cases, showed similar degrees of resistance to the standard S. habrochaites var. hirsutum PI-127826, which was expected due to the high heritability (81.9\%) of zingiberene content character in plants [22,25].

Normally, the genetic inheritance of a concentration of allelochemicals associated with the presence of glandular trichomes on tomato species is mediated by at most two larger genes, and is associated with smaller genes with an additive effect. The heritability in a broad sense was estimated at above $50 \%$, considered as moderate to high [41-43]. Heterozygous genotypes for zingiberene showed levels of allelochemicals intermediate to those of their parents of high and low content, indicating incomplete dominant gene action for the content of allelochemicals [7].

The concentration of this allelochemical is controlled by the two larger gene loci, with incomplete dominance in the sense of the lowest content in populations of interspecific crosses of S. lycopersicum with S. habrochaites var. hirsutum [22]. Other studies related to the presence of zingiberene reported that genetic inheritance was controlled by a single dominant gene of $S$. habrochaites var. hirsutum in the generation $\mathrm{F}_{2}$ and in the $\mathrm{BC}$ progeny of $S$. lycopersicum with $S$. habrochaites var. hirsutum, and also as a single recessive gene in the $\mathrm{F}_{2}$ generation and in the $\mathrm{BC}$ progeny of $S$. habrochaites var. hirsutum $\times$ S. habrochaites var. glabratum $[33,44]$.

This fact, together with the high heritability of the character, may reflect satisfactory genetic gains in backcrossing over generations, using indirect selection for resistance to arthropod pests based on the zingiberene content [25]. The most important aspect of the genetic breeding is hereditary variability and, particularly, the genetic component, which has a strong influence on the response to selection. The information generated from the character association studies appeared as an important indicator for a selection program. The present study also contributed to the suitability of several characters for indirect selection, because the selection for one or more characteristics resulted in a correlated response in several other studies [45]. 
The two larger gene loci are located very close to each other on chomosome 8 (ShZIS and ShSBS) [40]. However, it is assumed that only one of the gene loci is primarily responsible for the synthesis of zingiberene [44]. Evidence suggested that this locus must contain ShZIS synthase, which produces 7-epizingiberene, a zingiberene sesquiterpene stereomer, in glandular trichomes from Z-Z-farnesyl-diphosphate (zFPP) in plastids, which promotes resistance to various tomato pests.

It is also assumed that ShZIS is allelic to ShSBS and linked to zFPS. Gonzales-Vigil et al. [46] suggested that ShZIS originated before ShSBS, with the mutagenesis of only three amino acids at the active site of a synthesizing enzyme, predominantly zingiberene, elucidating the probable pathway for the synthesis of this sesquiterpene. Thus, indirect selection for resistance facilitated the process of genetic improvement, as it allows the use of tools that minimize the difficulties of selecting in large populations of plants, as in the case of segregating populations [7].

The environment can interfere in expression of zingiberene content, and thus low heritability can be great challenge for breeding programs. In-depth knowledge of quantitative genetic parameters and, in particular, genetic variation and heritability, help to overcome these challenges. Although the expression of the characters is influenced by the environment, the high heritability described in the literature implies success in transfer to progeny through crosses [47].

The high heritability of the traits is the fundamental basis for the genetic improvement of this particular trait. In addition, the nature and magnitude of genetic variation that governs inheritance of yield and yield components are essential for breeding. In general, heritability is the reason for variation due to differences between genotypes and the total phenotypic variation of a trait in a population [48]. Heritability estimates, along with genetic advancement, are more accurate in predicting genetic gain under selection than heritability alone. In addition, the relationship between the yield and the characteristics attributable to yield is of high importance for the direct and indirect selection of characteristics [49].

Resistance depends on the relationship of the target insect to the levels of zingiberene. The bioassays provided important results, inferring that the adults of T. urticae (Figure 2) and B. tabaci (Table 3) rejected the genotypes with high zingiberene content. For these two arthropods, the number of eggs deposited on leaflets of the susceptible standard treatment (S. lycopersicum cv. Redenção) and the low zingiberene genotype was higher compared to the high content genotypes and $S$. habrochaites var. hirsutum.

The results of this work corroborated the research of others who evaluated the selection of genotypes from different generations resulting from interspecific crosses between $S$. habrochaites var. hirsutum and S. lycopersicum. Interspecific hybrids with a high content of zingiberene, derived from a diallel and demonstrated by means of GCA (General Combining Ability) and SCA (Specific Combining Ability), have a high potential for use in improving tomato pest resistance [50]. Studies reported that genes responsible for high levels of zingiberene were passed to segregating generations through crosses, maintaining the resistance of plants in advanced populations with commercial backgrounds $[20,40,51]$.

The high number of eggs deposited by T. urticae (Table 2), B. tabaci (Table 3), and T. absoluta (Table 4) on the leaflets of the RVTZ genotype 2011-79-117-273 demonstrated that, although it has a low zingiberene content, it is highly susceptible to the evaluated pests. Studies with other tomato lines have also shown a positive correlation between zingiberene content and resistance to these pest arthropods [7,52,53]. Genotypes with a high zingiberene content (ZGB-703 and ZGB-704) had a lower oviposition and a lower number of nymphs of whitefly when compared with genotypes with a low acyl-sugar (AS) and zingibrene content (Santa Clara, TOM-695, TOM-556, and TOM-584) [54].

Bleeker et al. [46] observed a severe reduction in the fertility of two of the main tomato pests, B. tabaci and T. urticae, mediated by a zingiberene stereoisomer, 7-epizingiberene, also present in the PI-127826 genotype. Bleeker et al. [40] found that the survival rate and reproductive success of B. tabaci adults in $\mathrm{F}_{2}$ genotypes from the cross between PI-127826 and S. lycopersicum were severely compromised, although the levels of 7-epizingiberene on the $F_{2}-7$ and $F_{2}-71$ leaf surface were lower than that observed in wild tomato PI-127826. 
For T. absoluta, although adults remained on the leaflets of genotypes with high levels of zingiberene, their rejection was verified by the reduced number of eggs deposited compared to the susceptibility standard and the low allelochemical content genotype (Table 4). Homozygous lines with a high zingiberene content, simple heterozygous genotypes for zingiberene, and controls with a low zingiberene content ('Débora Max' and 'TOM-684') and a high zingiberene content (PI-127826) were subjected to infestation with adult pinworm from South America. High zingiberene genotypes showed significantly lower egg counts than the low ones [7]. The damage by T. absoluta was greater in the low zingiberene controls, as in the present study.

Silva et al. [55] found that volatile compounds such as sesquiterpenes negatively affected the preference (antixenosis) or survival (antibiosis) of herbivorous insects in tomatoes by modulating the flight behavior and oviposition of females of T. absoluta during mating. In addition, they observed that females landed more frequently and oviposited in the most susceptible genotype. However, this proportions of preference for feeding and oviposition were not substantially higher in the resistant genotypes when compared to susceptible ones.

Al-Bayati [56], when evaluating nine tomato hybrids $\left(\mathrm{BC}_{3} \mathrm{~F}_{3}\right.$ and $\left.\mathrm{BC}_{3} \mathrm{~F}_{4}\right)$ selected based on the variation of the type IV trichome density and zingiberene concentration of an interspecific cross with S. habrochaites, concluded that the resistance to the spider mite had been successfully transferred to hybrids through backcrossing and indirect selection. There was a significant negative correlation between almost all the behavioral and biological responses of the mites with the density of type IV trichomes and the zingiberene content. Therefore, these results are in agreement with those obtained in the present study for the relationship between zingiberene and pests.

The results of this work showed that the genotypes with a high zingiberene content affected the behavior and development of arthropods. Thus, it confirms that the use of $S$. habrochaites var. hirsutum PI-127826 enabled the introgression of genes to increase the degrees of resistance in the $\mathrm{F}_{2} \mathrm{BC}_{2}$ genotypes. Finally, the results suggested that the genotypes RVTZ 2011-79-503-143, RVTZ 2011-79-335-164, and RVTZ 2011-79-185-250 can be used as potential sources of genes for resistance to T. urticae, B. tabaci, and T. absoluta in tomato breeding programs. The results also showed that the genetic improvement of this species, mediated by allelochemicals present in wild species, is an excellent alternative for obtaining cultivars with better adaptation to sustainable production systems.

Author Contributions: Methodology, validation, and original draft preparation, J.R.F.d.O.; project administration and funding acquisition, J.T.V.d.R.; methodology and validation, R.B.d.L.F. and C.R.; review and editing, S.R.R. and P.R.d.S.; formal analyses, review and editing, and funding acquisition, C.N. All authors have read and agreed to the published version of the manuscript.

Funding: This research was supported by the National Institute of Science and Technology-Semiochemicals in Agriculture (FAPESP and CNPq-Grants \#2014/50871-0 and \#465511/2014-7, respectively). Support Program for Centers of Excellence (Pronex-FA/CNPq (PI) \#01/2018). J.R.F.d.O. was sponsored partially by the Coordination for the Improvement of Higher Education Personnel (CAPES Finance Code \#001).

Acknowledgments: The authors thank the anonymous reviewers for their helpful comments.

Conflicts of Interest: The authors declare no conflict of interest.

\section{References}

1. Fantke, P.; Jolliet, O. Life cycle human health impacts of 875 pesticides. Int. J. Life Cycle Assess. 2016, 21, 722-733. [CrossRef]

2. Pang, N.; Fan, X.; Fantke, P.; Zhao, S.; Hu, J. Dynamics and dietary risk assessment of thiamethoxam in wheat, lettuce and tomato using field experiments and computational simulation. Environ. Pollut. 2020, 256, 113285. [CrossRef] [PubMed]

3. Michelotto, M.D.; Carrega, W.C.; Pirotta, M.Z.; de Godoy, I.J.; Lourencao, A.L.; Martins, A.L.M. Control of thips ('Enneothips flavens' Moulton.) with synthetic and biological insecticides in different peanut genotypes. Aust. J. Crop Sci. 2019, 13, 1074. [CrossRef] 
4. Seki, K. Leaf-morphology-assisted selection for resistance to two-spotted spider mite Tetranychus urticae Koch (Acari: Tetranychidae) in carnations (Dianthus caryophyllus L.). Pest Manag. Sci. 2016, 72, 1926-1933. [CrossRef] [PubMed]

5. Stout, M.J.; Kurabchew, H.; Leite, G.L.D. Host-Plant Resistance in Tomato. In Sustainable Management of Arthropod Pests of Tomato; Elsevier: Amsterdam, The Netherlands, 2018; pp. 217-236.

6. Dawood, M.H.; Snyder, J.C. The alcohol and epoxy alcohol of zingiberene, produced in trichomes of wild tomato, are more repellent to spider mites than zingiberene. Front. Plant Sci. 2020, 11, 35. [CrossRef] [PubMed]

7. Maluf, W.R.; de Fátima Silva, V.; das Graças Cardoso, M.; Gomes, L.A.A.; Neto, Á.C.G.; Maciel, G.M.; Nízio, D.A.C. Resistance to the South American tomato pinworm Tuta absoluta in high acylsugar and/or high zingiberene tomato genotypes. Euphytica 2010, 176, 113-123. [CrossRef]

8. Dias, D.; Resende, J.; Marodin, J.; Matos, R.; Lustosa, I.; Resende, N. Acyl sugars and whitefly (Bemisia tabaci) resistance in segregating populations of tomato genotypes. Genet. Mol. Res. 2016, 15, 1-11. [CrossRef] [PubMed]

9. Lucini, T.; Faria, M.V.; Rohde, C.; Resende, J.T.V.; de Oliveira, J.R.F. Acylsugar and the role of trichomes in tomato genotypes resistance to Tetranychus urticae. Arthropod-Plant Interact. 2015, 9, 45-53. [CrossRef]

10. Goiana, E.S.; Dias-Pini, N.S.; Muniz, C.R.; Soares, A.A.; Alves, J.C.; Vidal-Neto, F.C.; Bezerra Da Silva, C.S. Dwarf-cashew resistance to whitefly (Aleurodicus cocois) linked to morphological and histochemical characteristics of leaves. Pest Manag. Sci. 2020, 76, 464-471. [CrossRef]

11. Cherif, A.; Verheggen, F. A review of Tuta absoluta (Lepidoptera: Gelechiidae) host plants and their impact on management strategies. Biotechnol. Agron. Société Environ. 2019, 23, 270-278.

12. Silva, A.A.D.; Carvalho, R.D.C.; Andrade, M.C.; Zeist, A.R.; Resende, J.T.V.D.; Maluf, W.R. Glandular trichomes that mediate resistance to green peach aphid in tomato genotypes from the cross between S. galapagense and S. lycopersicum. Acta Sci. Agron. 2019, 41, e42704. [CrossRef]

13. Follett, P.A. Insect-plant interactions: Host selection, herbivory, and plant resistance-an introduction. Entomol. Exp. Appl. 2017, 162, 1-3. [CrossRef]

14. Lucini, T.; Resende, J.; Oliveira, J.; Scabeni, C.; Zeist, A.; Resende, N. Repellent effects of various cherry tomato accessions on the two-spotted spider mite Tetranychus urticae Koch (Acari: Tetranychidae). Genet. Mol. Res. 2016, 15, 10.4328. [CrossRef] [PubMed]

15. Sohabi, F.; Nooryazdan, H.; Gharati, B.; Saeidi, Z. Plant resistance to the moth Tuta absoluta (Meyrick) (Lepidoptera: Gelechiidae) in tomato cultivars. Neotrop. Entomol. 2017, 46, 203-209. [CrossRef] [PubMed]

16. Savi, P.; De Moraes, G.; Junior, A.B.; Melville, C.; Carvalho, R.; LourenÇÃO, A.; Andrade, D. Impact of leaflet trichomes on settlement and oviposition of Tetranychus evansi (Acari: Tetranychidae) in African and South American tomatoes. Syst. Appl. Acarol. 2019, 24, 2559-2576.

17. Yao, Q.; Peng, Z.; Tong, H.; Yang, F.; Xing, G.; Wang, L.; Zheng, J.; Zhang, Y.; Su, Q. Tomato plant flavonoids increase whitefly resistance and reduce spread of tomato yellow leaf curl virus. J. Econ. Entomol. 2019, 112, 2790-2796. [CrossRef]

18. Ali, A.; Rakha, M.; Shaheen, F.A.; Srinivasan, R. Resistance of certain wild tomato (Solanum spp.) accessions to Helicoverpa armigera (Hübner) (Lepidoptera: Noctuidae) based on choice and no-choice bioassays. Fla. Entomol. 2019, 102, 544-548. [CrossRef]

19. Rakha, M.; Hanson, P.; Ramasamy, S. Identification of resistance to Bemisia tabaci Genn. in closely related wild relatives of cultivated tomato based on trichome type analysis and choice and no-choice assays. Genet. Resour. Crop Evol. 2017, 64, 247-260. [CrossRef]

20. Oliveira, J.; Resende, J.; Maluf, W.; Lucini, T.; Lima Filho, R.; Lima, I.; Nardi, C. Trichomes and allelochemicals in tomato genotypes have antagonistic effects upon behavior and biology of Tetranychus urticae. Front. Plant Sci. 2018, 9, 1132. [CrossRef]

21. Tissier, A. Glandular trichomes: What comes after expressed sequence tags? Plant J. 2012, 70, 51-68. [CrossRef]

22. Lima, I.; Resende, J.; Oliveira, J.; Faria, M.; Resende, N.; Lima-Filho, R. Indirect selection of industrial tomato genotypes rich in zingiberene and resistant to Tuta absoluta Meyrick. Genet. Mol. Res. 2015, 14, 15081-15089. [CrossRef]

23. Zhou, F.; Pichersky, E. More is better: The diversity of terpene metabolism in plants. Curr. Opin. Plant Biol. 2020, 55, 1-10. [CrossRef] 
24. Andrade, M.C.; Da Silva, A.A.; Neiva, I.P.; Oliveira, I.R.C.; De Castro, E.M.; Francis, D.M.; Maluf, W.R. Inheritance of type IV glandular trichome density and its association with whitefly resistance from Solanum galapagense accession LA1401. Euphytica 2017, 213, 52. [CrossRef]

25. Zanin, D.S.; Resende, J.T.; Zeist, A.R.; Oliveira, J.R.; Henschel, J.M.; Lima Filho, R.B. Selection of processing tomato genotypes resistant to two spotted spider mite. Hortic. Bras. 2018, 36, 271-275. [CrossRef]

26. Quesada-Ocampo, L.; Vargas, A.; Naegele, R.; Francis, D.; Hausbeck, M. Resistance to crown and root rot caused by Phytophthora capsici in a tomato advanced backcross of Solanum habrochaites and Solanum lycopersicum. Plant Dis. 2016, 100, 829-835. [CrossRef] [PubMed]

27. Resende, J.; da Silva, A.; Gabriel, A.; Zeist, A.; Favaro, R.; Nascimento, D.; Zeist, R.; Camargo, C. Resistance to Helicoverpa armigera mediated by zingiberene and glandular trichomes in tomatoes for industrial processing. Genet. Mol. Res. 2018, 17. [CrossRef]

28. Carter, C.D.; Snyder, J.C. Mite responses in relation to trichomes of Lycopersicon esculentum $x$ L. hirsutum F 2 hybrids. Euphytica 1985, 34, 177-185. [CrossRef]

29. Zeist, A.R.; da Silva, A.A.; de Resende, J.T.V.; Maluf, W.R.; Gabriel, A.; Zanin, D.S.; Guerra, E.P. Tomato breeding for insect-pest resistance. In Recent Advances in Tomato Breeding and Production; Intech Open: London, UK, 2018.

30. Heinz, K.M.; Zalom, F.G. Variation in trichome-based resistance to Bemisia argentifolii (Homoptera: Aleyrodidae) oviposition on tomato. J. Econ. Entomol. 1995, 88, 1494-1502. [CrossRef]

31. Nombela, G.; Beitia, F.; Muñiz, M. Variation in tomato host response to Bemisia tabaci (Hemiptera: Aleyrodidae) in relation to acyl sugar content and presence of the nematode and potato aphid resistance gene Mi. Bull. Entomol. Res. 2000, 90, 161-167. [CrossRef]

32. Leite, G.; Picanço, M.; Guedes, R.; Zanuncio, J. Role of plant age in the resistance of Lycopersicon hirsutum $f$. glabratum to the tomato leafminer Tuta absoluta (Lepidoptera: Gelechiidae). Sci. Hortic. 2001, 89, 103-113. [CrossRef]

33. De Freitas, J.A.; Maluf, W.R.; das Graças Cardoso, M.; de Oliveira, A.C.B. Seleção de plantas de tomateiro visando à resistência à artrópodes-praga mediada por zingibereno. Acta Sci. Agron. 2000, 22, 919-923. [CrossRef]

34. Statsoft, I. STATISTICA (Data Analysis Software System); Version 11; Science Open: Berlin, Germany, 2012.

35. Lin, H.; Kogan, M.; Fischer, D. Induced resistance in soybean to the Mexican bean beetle (Coleoptera: Coccinellidae): Comparisons of inducing factors. Environ. Entomol. 1990, 19, 1852-1857. [CrossRef]

36. Baldin, E.; Vendramim, J.; Lourenção, A. Resistência de genótipos de tomateiro à mosca-branca Bemisia tabaci (Gennadius) biótipo B (Hemiptera: Aleyrodidae). Neotrop. Entomol. 2005, 34, 435-441. [CrossRef]

37. Baldin, E.; Toscano, L.; Lima, A.; Lara, F.; Boiça, A., Jr. Preferência para oviposição de Bemisia tabaci biótipo B por genótipos de Cucurbita moschata e Cucurbita maxima. Boletín Sanid. Vegetal. Plagas 2000, 26, 409-413.

38. Sperotto, R.A.; Grbic, V.; Pappas, M.; Leiss, K.; Kant, M.; Wilson, C.R.; Santamaria, M.E.; Gao, Y. Plant responses to phytophagous mites/thips and search for resistance. Front. Plant Sci. 2019, 10, 866. [CrossRef]

39. Glas, J.J.; Schimmel, B.C.; Alba, J.M.; Escobar-Bravo, R.; Schuurink, R.C.; Kant, M.R. Plant glandular trichomes as targets for breeding or engineering of resistance to herbivores. Int. J. Mol. Sci. 2012, 13, 17077-17103. [CrossRef]

40. Bleeker, P.M.; Mirabella, R.; Diergaarde, P.J.; VanDoorn, A.; Tissier, A.; Kant, M.R.; Prins, M.; de Vos, M.; Haring, M.A.; Schuurink, R.C. Improved herbivore resistance in cultivated tomato with the sesquiterpene biosynthetic pathway from a wild relative. Proc. Natl. Acad. Sci. USA 2012, 109, 20124-20129. [CrossRef]

41. Saeidi, Z.; Mallik, B.; Kulkarni, R. Inheritance of glandular trichomes and two-spotted spider mite resistance in cross Lycopersicon esculentum "Nandi”and L. pennellii “LA2963". Euphytica 2007, 154, 231-238. [CrossRef]

42. Alba, J.M.; Montserrat, M.; Fernández-Muñoz, R. Resistance to the two-spotted spider mite (Tetranychus urticae) by acylsucroses of wild tomato (Solanum pimpinellifolium) trichomes studied in a recombinant inbred line population. Exp. Appl. Acarol. 2009, 47, 35-47. [CrossRef]

43. Rodríguez-López, M.; Garzo, E.; Bonani, J.; Fereres, A.; Fernández-Muñoz, R.; Moriones, E. Whitefly resistance traits derived from the wild tomato Solanum pimpinellifolium affect the preference and feeding behavior of Bemisia tabaci and reduce the spread of Tomato yellow leaf curl virus. Phytopathology 2011, 101, 1191-1201. [CrossRef]

44. Rahimi, F.; Carter, C. Inheritance of zingiberene in Lycopersicon. Theor. Appl. Genet. 1993, 87, 593-597. [CrossRef] [PubMed] 
45. Dutta, P.; Hazari, S.; Karak, C.; Talukdar, S. Study on genetic variability of different tomato (Solanum lycopersicum) cultivars grown under open field condition. IJCS 2018, 6, 1706-1709.

46. Gonzales-Vigil, E.; Hufnagel, D.E.; Kim, J.; Last, R.L.; Barry, C.S. Evolution of TPS20-related terpene synthases influences chemical diversity in the glandular trichomes of the wild tomato relative Solanum habrochaites. Plant J. 2012, 71, 921-935. [CrossRef]

47. Zörb, C.; Piepho, H.-P.; Zikeli, S.; Horneburg, B. Heritability and variability of quality parameters of tomatoes in outdoor production. Research 2020, 2020, 6707529. [CrossRef]

48. Adhikari, B.; Joshi, B.; Shestha, J.; Bhatta, N. Genetic variability, heritability, genetic advance and trait association study for yield and yield components in advanced breeding lines of wheat. Nepal. J. Agric. Sci. 2018, 17, 229.

49. Aditya, J.; Bhartiya, A. Genetic variability, correlation and path analysis for quantitative characters in rainfed upland rice of Uttarakhand hills. J. Rice Res. 2013, 6, 24-34.

50. Fernández-Muñoz, R.; Salinas, M.; Álvarez, M.; Cuartero, J.s. Inheritance of resistance to two-spotted spider mite and glandular leaf trichomes in wild tomato Lycopersicon pimpinellifolium (Jusl.) Mill. J. Am. Soc. Hortic. Sci. 2003, 128, 188-195. [CrossRef]

51. Lima, I.P.; Resende, J.T.; Oliveira, J.R.; Faria, M.V.; Dias, D.M.; Resende, N.C. Selection of tomato genotypes for processing with high zingiberene content, resistant to pests. Hortic. Bras. 2016, 34, 387-391. [CrossRef]

52. Neiva, I.P.; Andrade Júnior, V.C.d.; Maluf, W.R.; Oliveira, C.M.; Maciel, G.M. Role of allelochemicals and trichome density in the resistance of tomato to whitefly. Ciência Agrotecnol. 2013, 37, 61-67. [CrossRef]

53. Oliveira, C.M.d.; Andrade Júnior, V.C.d.; Maluf, W.R.; Neiva, I.P.; Maciel, G.M. Resistance of tomato strains to the moth Tuta absoluta imparted by allelochemicals and trichome density. Ciência Agrotecnol. 2012, 36, 45-52. [CrossRef]

54. Neiva, I.P.; Silva, A.A.d.; Resende, J.F.; Carvalho, R.d.C.; Oliveira, A.M.S.d.; Maluf, W.R. Tomato genotype resistance to whitefly mediated by allelochemicals and Mi gene. Chil. J. Agric. Res. 2019, 79, 124-130. [CrossRef]

55. Silva, D.B.; Weldegergis, B.T.; Van Loon, J.J.; Bueno, V.H. Qualitative and quantitative differences in herbivore-induced plant volatile blends from tomato plants infested by either Tuta absoluta or Bemisia tabaci. J. Chem. Ecol. 2017, 43, 53-65. [CrossRef] [PubMed]

56. AL-Bayati, A.S. Breeding for Tomato Resistance to Spider Mite Tetranychus urticae Koch (Acari: Tetranychidae); University of Kentucky: Lexington, KY, USA, 2019. 